\title{
$\mathrm{KDC}$ 제6판 건축학 분야의 분류체계 개선방안
}

\section{A Study on Improvements of Construction and Architecture Fields in the 6th Edition of Korean Decimal Classification}

\author{
김송이 (Songie Kim)* \\ 정연경 (Yeon Kyoung Chung)**
}

\begin{abstract}
초 록
한국십진분류법(Korea Decimal Classification) 5 판에서는 건축학 분야가 건축공학과 건축술이라 는 두 항목으로 나뉘어 분류되었으나 2013년 6판에서는 '건축, 건축학'으로 통합되었다. 본 연구는 $\mathrm{KDC}$ 5 판과 $\mathrm{KDC} 6$ 판의 비교 분석과 $\mathrm{DDC}, \mathrm{NDC}, \mathrm{UDC}$ 의 비교 분석을 통하여 개정된 $\mathrm{KDC} 6$ 판의 건축학 분야를 살펴보고 개선방안을 제안하였다. 주요 십진분류법과의 비교 분석결과 건축학은 항목 통합으로 인한 재분류의 필요성, 이전보다 길어진 건축사 분류번호 문제가 발생하였으며, 한국 전통 건축에 대한 분류 전개 개선이 필요한 것으로 나타나 이에 대한 개선방안을 제안하였다.
\end{abstract}

\section{ABSTRACT}

Constructions and Architecture fields were divided into Architecture engineering and Architecture in the 5th edition of Korean Decimal Classification (KDC), but those were combined in the 6th edition of KDC published in 2013. The purposes of this study are to find problems and to suggest modifications through comparing and analyzing the 5th and the 6th editions of KDC, Dewey Decimal Classification, Nippon Decimal Classification and Universal Decimal Classification. The necessity of reclassification, a long classification number for History of Architecture and addition of categories of traditional building and architectural engineering are required to improve the 6th edition of $\mathrm{KDC}$ and the improvements and modifications of those problems are suggested.

키워드: 한국십진분류법, 건축, 건축학, 건축공학, 십진분류법

Korean Decimal Classification, construction, architecture, architecture engineering, decimal classification

* 이화여자대학교 일반대학원 문헌정보학 전공 박사과정(inmylibrary@hanmail.net) (제1저자)

**이화여자대학교 사회과학대학 문헌정보학 전공 교수(ykchung@ewha.ac.kr) (교신저자)

- 논문접수일자 : 2014년 8월 1일 - 최초심사일자 : 2014년 8월 28일 - 게재확정일자 : 2014년 9월 17일

- 정보관리학회지, 31(3), 7-27, 2014. [http://dx.doi.org/10.3743/KOSIM.2014.31.3.007〕 


\section{1. 서 론}

한국십진분류법(Korea Decimal Classification, 이하 $\mathrm{KDC}$ )은 듀이십진분류법(Dewey Decimal Classification, 이하 DDC), 일본십진분류법(Nippon Decimal Classification, 이하 NDC), 국제십진 분류법(Universal Decimal Classification, 이하 $\mathrm{UDC}$ )을 참고하여 한국 도서관을 위해 한국도 서관협회의 분류전문위원회에서 개발한 십진 분류법이다. $\mathrm{KDC}$ 가 개정될 때마다 각 학문 분 야별 주요 십진분류법과의 비교 분석은 꾸준히 이루어졌으며 2013년에 KDC 6판이 발간된 후, 디자인학과 약학, 체육학 분야의 연구가 나왔 고 앞으로 다양한 학문분야에 대한 유사 연구 가 진행될 것이다.

$\mathrm{KDC}$ 6판에서 가장 크게 달라진 부분은 건축 학 분야에 대한 학문분류체계의 통합이다. $\mathrm{KDC}$ 5 판에서 건축학은 600 예술 아래에서 610 으로 전개되었던 건축술과 500 기술과학 아래 540 에 전개되었던 건축공학으로 나뉘어 있었다. 그러 나 $\mathrm{KDC} 6$ 판에서는 건축학을 540 '건축, 건축학' 으로 통합 - 전개하였다. 이는 $\mathrm{KDC} 5$ 판을 사용 하던 도서관에서 6 판을 도입할 경우 도서관의 기존 분류체계를 흔들만할 큰 변화이다. 그러므 로 건축학 분야에 대한 $\mathrm{KDC} 5$ 판에서 6 판으로 의 변화를 짚어보고, 다른 주요 십진분류법과의 비교 분석을 통해 $\mathrm{KDC}$ 6판 건축학 분야의 장점 과 단점을 살펴보고 이에 대한 개선 방안을 제 안하고자 한다.

\section{1 연구의 목적 및 방법}

본 연구의 목적은 $\mathrm{KDC} 6$ 판에서 많은 변화를
가져온 '건축, 건축학'의 분류체계를 대상으로, $\mathrm{KDC} 5$ 판과 6 판을 먼저 비교한 후, 주요 십진분 류법과도 대조하여 6 판에서의 개정이 가지는 의 미와 문제점을 바탕으로 개선방안을 제시하는 데 있다.

본 연구에서는 먼저 건축학 분야 분류 전개 에 대한 선행 연구를 살펴보고 $\mathrm{KDC} 5$ 판과 6 판 의 건축학 분야의 비교를 통해 분류 전개상의 차 이를 분석하였다. 또한 주요 문헌분류표인 $\mathrm{DDC}$ 23판(2011)과 NDC 신정9판(1995), UDC(2005) 의 건축학 분야 분류 항목 및 전개를 비교 분 석하였다. 이를 통해 $\mathrm{KDC} 6$ 판의 건축학 분야 개정 부분과 해당 부분이 가지는 의미, 그리고 이러한 개정이 $\mathrm{KDC}$ 를 이용하고 있는 도서관 에 미치는 영향과 문제점, 개선 방안을 도출하 였다.

\section{2 선행연구}

선행연구는 크게 건축학 분야의 주제 전개에 대한 분석 연구와 $\mathrm{KDC} 6$ 판에 대한 비교 연구 로 나눌 수 있다.

먼저 건축학 분야의 주제 전개에 대한 연구는 윤춘섭(1995, 1999, 2001, 2002), 김연례(2009) 와 여지숙, 공성훈, 오동근(2013)에 의해 꾸준 히 진행되었다. 윤춘섭(1995)은 KDC가 국내 대 부분의 공공도서관과 여러 대학도서관, 건축 전 문도서관에서 사용되고 있지만, 건축 관련 분야 의 개정에 건축전문가들이 배제되었다는 사실 을 지적하고 $\mathrm{KDC}$ 의 건축 분야 활용 실태를 살 펴 문제점을 지적하였다. 이어 윤춘섭(1999)은 1996년에 발간된 KDC 4판에서 540 건축공학 분야를 분석하여 그 개선점을 도출하였다. 4 판 
은 항목이 이전보다 세분되었으나, $\mathrm{DDC}$ 를 반 영하는 과정에서 번역상의 오류로 원래 의미와 달라진 부분이 있으며 건축 설비의 항목들이 기 타 학문으로 분산된 점을 지적하면서 차후 $\mathrm{KDC}$ 개정에 건축전문가들이 참여할 것을 제안하였 다. 이후 윤춘섭(2001)은 $\mathrm{KDC} 3$ 판과 4판을 비 교하고, $\mathrm{DDC} 21$ 판의 항목을 연계 분석하여 610 건축술의 개선 방안을 새로이 제안하였다. 이 상의 연구를 바탕으로 윤춘섭(2002)은 인터넷 서점의 건축도서 분류에 관한 연구를 수행하였 는데, 대형 인터넷 서점 두 곳과 건축도서 전문 서점 두 곳을 분석 대상으로 선정하고 분류구조 와 항목별 도서수를 확인하여 분류정확률로 평 가하였다. 그 결과 비체계적이고 부정확한 건축 도서의 분류를 해결하기 위해서는 건축술과 건 축공학을 하나로 보는 사회적 인식의 재고와, 점차 변화하는 건축학 관련 학문의 정보를 관리 할 수 있는 건축정보 전문가 양성이 필요함을 주장하였다.

김연례(2009)는 $\mathrm{KDC} 5$ 판의 개정에 맞춰 $\mathrm{KDC}$ 4 판과 $\mathrm{KDC} 5$ 판의 건축공학분야를 비교분석하 였으며, DDC와 LCC (Library of Congress Classification: 미국국회도서관분류표)의 항목, 한 국학술진흥재단과 한국과학재단의 연구분야 분 류체계를 추가 분석하여 $\mathrm{KDC} 5$ 판의 건축공학 분야 분류체계 개선방안을 제시하였다.

여지숙, 공성훈, 오동근(2013)은 문헌분류 전 문가와 건축학 전문가의 협업으로 연구를 진행 하였는데 $\mathrm{KDC}, \mathrm{DDC}, \mathrm{NDC}$, 학술연구분야분류 표, 국가과학기술표준분류표의 비교분석을 바탕 으로 KDC 5 판에서 540 건축공학과 610 건축술 을 통합하는 개선안을 제시하였다. 이 연구는 건 축술 이용자가 건축공학 역시 함께 이용하고 있
으므로 두 분야를 통합하고 학분 분야에서 비 중이 높고 관련 도서가 많은 건축사 항목을 비 중 있게 전개하며, 세부 전개가 부족한 건축공 학 내 여러 분야의 확충이 필요하다고 제안하 였다.

$\mathrm{KDC}$ 6판의 타 분야에 관한 개선방안 연구로, 김수정(2013)은 $\mathrm{KDC}$ 6판의 디자인학 분야 개 선방안을 제안하기 위해 기존의 연구와 $\mathrm{KDC}$, $\mathrm{DDC}, \mathrm{LCC}, \mathrm{NDC}$ 를 비교 분석하였다. 여기에 『대한민국 국가서지 2011』을 이용하여 KDC 5 판을 기준으로 각 분야별 장서수를 확인하여 출판량이 집중된 디자인 이론분야와 디자인 응 용분야에 세목을 추가 전개하였고, 디지털 디 자인과 관련된 항목을 004.76 의 멀티미디어 응 용에 추가하였으며, 응용분야의 저작 분류를 위해 주기의 추가를 제안하였다.

정옥경, 이장익, 최정희(2013)는 $\mathrm{KDC}$ 6판의 약학 분야 분류항목에 대한 개선 방안을 제시하 기 위해 약학 분야의 변천을 $\mathrm{KDC}$ 약학 분야에 서 살펴보고, DDC, NLMC(National Library of Medicine Classification), 한국학술진흥재단 의 연구분야 분류표와의 비교분석을 실시하였 다. 그 결과 $\mathrm{KDC} 6$ 판에 나타난 약학 분야의 용 어 오류와 오기를 지적하고 분류항목의 재배치 및 추가 전개를 제안하였으며 최신성이 결여되 었다는 점을 지적하였다.

이희진과 김정현(2013)은 $\mathrm{KDC}$ 6판을 중심으 로 체육학 분야의 분류체계 개선방안을 제안하 였다. 이를 위해 체육학의 학문적 체계를 분석하 고 한국연구재단의 학술연구분야 분류표와 교육 과학기술부의 국가과학기술표준분류체계 등 연 구분야 분류체계와 $\mathrm{DDC}, \mathrm{LCC}, \mathrm{NDC}$ 의 문헌 분 류체계와 비교한 뒤 『대한민국 국가서지 2012』 
의 체육학 분야 자료 수와 주제어를 추출 - 분석 하였다. 그 결과 $\mathrm{KDC}$ 의 분류체계는 스포츠 경기 위주로 전개되어 분과학문분야에 대한 분류항목 이 부족하며 이는 『대한민국 국가서지 2012』에 서 692(체육학, 스포츠)로 시작하는 서지가 전 체의 $59.2 \%$ 로 쏠려 있다는 점에서 확인할 수 있 었다.

곽철완(2014)은 도서관 분류법에 관한 국내 연구 동향을 분석하였는데, $\mathrm{KDC}$ 에 관한 연구 는 크게 학문 분야별 분류체계를 장서량, 일반 분류체계, 특정 학문의 분류체계로 분석하여 개 선방안을 제시하는 연구와 $\mathrm{KDC}$ 수정 전개안을 제시한 연구로 나눌 수 있다고 하였다.

이상과 같이 $\mathrm{KDC}$ 는 개정될 때마다 학문별 분류체계에 관한 분석이 꾸준히 이루어졌다. 그 중에서도 건축학 분야 분류체계 분석은 건축 전 문가와 문헌분류 전문가들을 중심으로 1995년 부터 2013년까지 이루어졌다. 하지만 6판으로 개정된 후, 건축 분야 분류체계에 관한 연구는 아직까지 이루어지지 않았다. 그러므로 6 판에서 달라진 부분을 $\mathrm{DDC}, \mathrm{NDC}, \mathrm{UDC}$ 의 해당 분야 와 비교 분석하고 각각의 특징을 살펴본 후, 이 를 바탕으로 6 판 적용시의 문제점을 짚어보고 향후 $\mathrm{KDC}$ 의 건축학 분야에 대한 개선 방안을 도출해내고자 한다.

\section{2. 건축학 및 분류의 개념}

\section{1 건축학의 정의}

건축 혹은 건축학에 대한 개념은 다양한 형 태로 기술된다. 브리태니커 온라인 한국어판 (http://preview.britannica.co.kr/)에서는 건 축학을 나타내는 항목을 'art of architecture' 로 쓰고 있다. 그리고 이를 '한 사회에서 필요로 하는 실제적인 요구와 표현 욕구를 충족시키는 건물을 설계하고 짓는 예술, 또는 그 기술'로 설 명하여 미학적 요인과 기술적 해결책이라는 두 가지 요소가 혼합된 것으로 보았다. 한국민족문 화대백과사전(http://encykorea.aks.ac.kr/)에 서는 '건물을 설계, 건립, 유지하기 위한 이론과 기술적 체계를 과학적으로 연구하는 학문'으로 건축학을 정의하며, 발생시초부터 기술과 예술 의 종합체로 성립되어 왔다고 설명하였다. 두산 세계대백과사전(http://www.doopedia.co.kr) 에서는 건축학을 '건축물의 설계·건축·유지 등을 위한 이론과 기술체계를 연구하는 학문' 으로, 건축공학을 '건축에 관한 구조·재료·계 획 · 공법 - 역학 - 환경문제 등을 연구하는 학문' 으로 정의하며 건축구조-건축환경계획 - 건축 설비의 분야로 구분된다고 하였다. 이와 같이 브 리태니커와 한국민족문화대백과사전은 건축학 을 예술적 요소와 기술적 요소로 크게 나누고 있 지만 두산 세계대백과사전은 통합적인 관점에서 정의를 내리고 건축공학을 건축학의 하부 영역 으로 다루고 있다.

\section{2 분류의 정의}

분류는 다양한 매체와 자료를 보유하고 있는 기관에서 자료를 유사한 것과 유사하지 않은 것 으로 구분하는 것이다. 그리고 도서관에서 분류 의 목적은 소장 자료를 체계적으로 관리하고 이 용자가 자료를 용이하게 이용할 수 있게 하는 것이다. 그러므로 문헌 분류체계는 다양한 학문 
분야의 구조를 반영하며, 지속적인 개정을 통 해 시대와 함께 해당 분야의 변화를 반영해야 한다. 그러나 개정 과정에서 분류의 전체적인 구조를 크게 변경하면, 새로운 판을 적용할 때 도서관에서는 기존 자료를 재분류하는 문제가 발생하고 이용자들의 혼란을 야기할 수 있으므 로 문헌 분류는 학문 변화의 반영과 분류기호 의 보존성이라는 두 원칙 사이에서 적절한 조 정이 필요하다.

\section{3. 주요 십진분류표 건축학 분야 분류항목 전개}

\subsection{DDC의 건축학}

$\mathrm{DDC}$ 는 아라비아 숫자와 연계하여, 구두점 앞 세 자리와 그 뒤의 숫자로 주제에 관한 분류 기호를 나타내는 십진식 분류표이다. $\mathrm{DDC}$ 는 주 제별로 분류기호를 열거하였으나 본표의 분류 기호에 여섯 개의 보조표를 추가 합성하여 확장 전개할 수 있다. 1876년 초판이 발행된 이후 여 러 번의 개정을 거쳤으며, 가장 최신판은 2011 년에 전체 4 권으로 출간된 23 판이다. $\mathrm{DDC}$ 의 분 류체계는 초판이 발간될 당시의 시대적 조류를 따라 학문에 의한 주제 분류를 하고 있으며, 000 총류를 제외한 아홉 가지의 학문분야가 이에 해 당한다.

$\mathrm{DDC}$ 에서 건축학은 600 기술과학 이래의 'Construction of buildings'와 700 예술 아래의 'Architecture'로 나뉜다. 전자는 '건축재료(Building materials)', '건축실무(Auxiliary construction practices)', '건축재료나 목적에 따른 구분(Con- struction in specific types of materials and for specific purpose)', '목건축(Wood construction)', '지붕마감(Roof covering)', '설비(Utilities)', '난 방(Heating)', '환기 및 공기조화(Ventilating, air-conditioning engineering)', '마감(Detail finishing)'을 다루고 있다. 후자는 기초나 벽 등의 건물 구조와 구조적 요소를 앞에서 다루며, 그 뒤에는 시대적 구분에 따라 고대 건축물, 중세 시대의 건축물, 근대의 건축물을 전개하고, 용 도에 따라 공공기관이나 정부, 상업시설, 무역 시설 및 농업설비를 다룬 건물과 종교적 건물, 교육이나 연구 목적의 건물, 주거용 건물을 분류 하며 마지막은 구조적이고 세부적인 부분의 설 계와 장식(Design and decoration of structures and accessories)을 다룬다.

이를 정리하면 $\mathrm{DDC}$ 에서 예술 분야의 건축학 은 완성품인 건축물 자체를 다룬 문헌을 대상으 로 하며, 기술공학 분야의 건축학은 건축물이 만들어지는 과정에 대한 문헌을 다룬다고 할 수 있다. 즉, $\mathrm{DDC}$ 는 앞서 다룬 브리태니커의 건축 학 정의에서처럼 기술과 예술을 분리하여 분류 하고 있다(〈표 1〉참조).

\subsection{NDC의 건축학}

$\mathrm{NDC}$ 는 현재 신정9판까지 발행되어 있으며 발행 시기가 1995년으로 상당히 오래되었다. 현 재 일본도서관협회에서는 2014년 내에 신정10 판을 출간하는 것을 목표로 공청회 등의 준비 를 진행 중이나 아직 완료되지 않았다. 따라서 타 분류표와 개정년도가 상당히 차이나지만 가 장 최신판에 해당하는 신정9판을 살펴보면 〈표 2)와 같다. 
〈표 1〉DDC 23판(2011) 건축학 관련 분야 분류항목명

\begin{tabular}{ll|ll}
\hline \multicolumn{2}{c|}{ DDC 23판(2011) 건축공학 분야의 항목명 } & \multicolumn{2}{c}{ DDC 23판(2011) 건축분야의 항목명 } \\
\hline 690 Construction of buildings & 720 Architecture \\
\hline 691 Building materials & 721 Architectural materials and structural elements \\
\hline 692 Auxiliary construction practices & 722 Architecture from earliest times to ca.300 \\
\hline $\begin{array}{l}\text { Construction in specific types of materials and } \\
\text { for specific purpose }\end{array}$ & 723 Architecture from ca.300 to 1399 \\
\hline 694 Wood construction & 724 Architecture from 1400 \\
\hline 695 Roof covering & 725 Public structures \\
\hline 696 Utilities & 726 Buildings for religious and related purposes \\
\hline 697 Heating, ventilating, air-conditioning engineering & 727 Buildings for educational and research purposes \\
\hline 698 Detail finishing & 728 Residential and related buildings \\
\hline
\end{tabular}

〈표 2〉NDC 신정9판(1995) 건축학의 분류항목명

\begin{tabular}{ll|l}
\hline & $\mathrm{NDC}$ 신정9판(1995) 건축학 분야의 항목명 \\
\hline 520 & 건축학 & 525 건축계획.시공 \\
\hline 521 & 일본의 건축 & 526 각종의 건축 \\
522 & 동양의 건축. 아시아의 건축 & 527 주택건축 \\
523 서양의 건축. 그외의 양식 건축 & 528 건축설비. 설비공학 \\
\hline 524 & 건축구조 & 529 건축의장 - 장식 \\
\hline
\end{tabular}

$\mathrm{NDC}$ 의 건축은 500 기술공학 아래에 놓여있 으며 $\mathrm{DDC}$ 와는 달리 예술 분야에는 전개되지 않 았다. 520 건축학 아래에서는 일본의 건축, 동양 의 건축, 서양 및 그 외 지역의 건축 등 건축물에 대한 분류를 앞에 전개했으며, 그 뒤에 공학적 측면에서 건축 구조와 건축설계 - 시공, 병원이 나 공공기관 등의 특정 건물, 주택건축을 다루고 마지막으로 주택의 설비, 건축 의장 양식을 다루 고 있다. 건물과 건축공학을 나눈 $\mathrm{DDC}$ 와는 달 리 NDC는 건축학을 통합적으로 보고 있으며, 예술적 측면에 해당되는 건축술 부분도 분류구 조 말미에 함께 넣고 있다.

\subsection{UDC의 건축학}

UDC는 1894년에 DDC 5판을 바탕으로 국제 서지를 편성에 사용하고자 하는 목적으로 개발 된 국제십진분류표이다(이창수, 2009). 첫 판이 나온 후, 각 국가별로 다양한 버전이 개발되었으 나 가장 최근 판은 British Standard Institution 에서 2005년과 2006년에 발행한 표준판(standard edition) 3 판이다. 표준판은 두 권으로 구성되어 있으며 제 1 권인 보조표 및 본표는 2005년에, 색 인에 해당하는 제 2 권은 2006년에 출간되었다. $\mathrm{UDC}$ 는 본표를 기반으로 다양한 보조표를 조합 
〈표 3〉UDC 표준3판(2005) 건축학 분야 분류항목명

\begin{tabular}{ll|ll}
\hline \multicolumn{2}{c|}{ UDC 표준3판(2005) 건축공학 분야의 항목명 } & \multicolumn{2}{c}{ UDC 표준3판(2005) 건축 분야의 항목명 } \\
\hline 69 & Building(Construction) Trade & 72 & Architecture \\
\hline 691 & Building materials & 721 & Buildings generally \\
\hline 692 & Structural parts and elements of buildings & 725 & Public, Civil, Commercial, Industrial buildings \\
\hline 693 & Masonry and related building craft & 726 & Religious Ecclesiastical architecture \\
\hline 694 & Timber construction. Carpentry. Joinery & 727 & Buildings for educational scientific, cultural purposes \\
\hline 696 & Equipments, Services, Installations in buildings & 728 & Domestic architecture. Hoseing. Residential buildings \\
\hline 697 & Heating, Ventilation and air conditioning of buildings & & \\
\hline 698 & Finishing and decoration trades & & \\
\hline
\end{tabular}

할 수 있으며 $\mathrm{DDC}$ 나 $\mathrm{KDC}$ 보다 훨씬 넓은 영역 에서 조합이 가능해 확장성이 높다는 특징을 가 진다.

$\mathrm{UDC}$ 본표의 구조는 $\mathrm{DDC}$ 와 유사한데, 의미 없는 0 은 사용하지 않으므로 69 에 '건축업, 건축 재료 건축 실제와 방법(Building trade, building materials, building practice and procedure)'을 다루고 있으며 72에 '건축술(Architecture)'을 분 류하고 있다. 69는 앞부분에 '건축재료(Building materials)', 벽, 지붕, 마루 등 '건물의 구조적 요소와 부분(Structural parts and elements of buildings)'을 다루고 그 뒤에 '석조건물(Masonry and related building craft)'과 '목구조(Timber construction)', '설비, 서비스 설치(Equipments, services, installations in buildings)', '난방과 환기 및 공기조화(Heating, ventilation and air conditioning of buildings' ${ }^{\prime}$ 를 다루고 마지막에 '마감과 장식(Finishing and decoration trades)' 을 놓고 있다.

72 건축물에서는 공공건물(Public, civil, commercial, industrial buildings) 과 종교건물, 교 육 및 연구 목적 건물을 다루고 뒤에서 주거용 건물을 다루고 있다. 즉, 건물의 용도에 따라 구
체적으로 나열하기 위해서는 보조표의 조합이 필요하다(〈표 3〉 참조).

\section{4. 주요 십진분류표별 비교분석}

\subsection{KDC 5판과 6판의 비교}

$\mathrm{KDC}$ 5판은 2009년에, 6 판은 2013년에 출간 되었다. 4년이라는 비교적 짧은 기간 안에 개정 되어 출간되었는데, 특히 건축학 부분에서는 엄 청난 변화가 있었다.

$\mathrm{KDC} 5$ 판의 건축학은 $\mathrm{DDC}$ 의 학문분류에 따 라 '건축공학'과 '건축술로 나뉘어 있었다. $\mathrm{KDC}$ 3 판(1999)과 4 판(2000)의 건축학 분야 분석을 한 윤춘섭은 건축술과 건축공학을 서로 다른 학 문 단위(윤춘섭, 2002)로 보고 있기 때문에 KDC 5 판에서 건축학 관련 문헌이 분리되어 분류되는 것 에 대하여 별다른 지적을 하지 않았다. 그러나 가장 최근에 이루어진 여지숙, 공성훈, 오동근(2013)의 연구에서는 건축공학과 건축술은 건축학이라는 같은 학문 분야의 이용자가 이용하기 때문에 양 쪽의 도서를 한 곳에 모아 분류하는 것이 옳다 
고 주장하고, 양쪽의 분류를 통합하는 분류표를 제안하였다. 그리고 $\mathrm{KDC} 6$ 판은 540 의 건축공 학 안에 610 의 건축술을 흡수 통합시키는 형태로 양쪽의 분류 체계를 하나로 만들었다. $\mathrm{KDC} 6$ 판 의 개정 내용은 여지숙, 공성훈, 오동근(2013)의 제안을 상당 부분 반영하였다.

〈표 4〉와 같이 KDC 6 판 건축학 분야의 명칭 은 $\mathrm{KDC} 5$ 판의 540 '건축공학', 610 '건축술'이 통합되면서, 540 '건축(建築), 건축학(建築學)' 으로 바뀌었다. 강(綱) 의 항목명이 변경되면서 540.1 의 '건축구조 일반'도 '건축계획'으로 변경 되고 540.2 의 '건축활동'은 542.1 로 이동했다. 5 판 542 '건축실무'의 세목인 '건축제도', '건축 제도'는 540.1 '건축계획' 아래로 이동했다. 542 는 '건축실무'에서 '건축 시공 및 적산'으로 항 목명이 바뀌었고, 542.1-.3의 변경 외에 542.9 항목명이 '기타 건축실무'에서 '기타 건축시공' 으로 바뀌며 하위에 안전대책과 유지보수가 추 가되었다.

543은 '건축구조의 유형'에서 '구조역학 및 건 축 일반구조로 항목명이 수정되었고, 이에 따 라 543.1이 '기초공학(토질)'에서 '구조역학'으 로 변경되고 이전 항목인 '기초공학(토질)'은 하
위개념으로 전개하였다. 또한 '구조물 분석'과 '파손과 파괴'가 그 뒤에 추가 전개되었다.

544 의 '친환경 건축'은 543.99에 놓였던 '특 정목적을 위한 건축'까지 포괄하는 '친환경건축 및 특정목적 건축'으로 변경되었고, 5 판의 544 '친환경 건축'은 그 아래 544.1로 이동했다. 따 라서 5 판에서 '친환경 건축' 하위에 있던 544.1 '설계 및 재료'와 544.2 '공법', 544.3 '유지관리', 544.4 '경제성'은 544.11-.14로 세분 전개되었 다. 544 '친환경건축 및 특정목적건축' 아래 '도 난방지구조', '내화구조', '해충방지구조', '충격 방지구조' 등 건축의 특수구조에 관한 항목명이 544.3.7에 추가 전개되었다.

545 는 세목에서의 변경사항이 없으며, 546은 항목명 앞부분에 건축환경이 추가되어 '건축환 경, 건축설비, 배관 및 파이프의 부설'로 바뀌었 고 이에 맞춰 5판에서 '급배수설비'였던 546.1은 '건축환경'으로 변경되었다. 그 아래에는 '열환 경', '빛환경', ‘음환경'의 항목이 추가되었다. '급 배수설비를 비롯한 여러 설비들은 546.2 부터 시 작해 하나씩 뒤로 밀렸으나 5 판의 546.5 가 비어 있었기 때문에 546.5-.9까지는 변동사항이 없다. 547 역시 세목에서의 변동사항은 없다.

〈표 4〉 KDC 5판과 6 판 건축 분야 비교: 540 건축 및 610 건축술의 전체 비교

\begin{tabular}{|c|c|c|c|}
\hline KDC 5판(2009) & KDC 6판(2013) & KDC 5판(2009) & KDC 6판(2013) \\
\hline $\begin{array}{l}540 \text { 건축공학 } \\
540.1 \text { 건축구조 일반 } \\
540.2 \text { 건축활동 }\end{array}$ & $\begin{array}{l}540 \text { 건축(建築), 건축학(建築學) } \\
\text { 540.1 건축계획 }\end{array}$ & \begin{tabular}{|l|}
$\frac{546 \text { 건축설비, 배관 및 파이프의 }}{\text { 부설 }}$ \\
$\frac{546.1 \text { 급배수설비 }}{546.2 \text { 가스 설비 }}$ \\
$\underline{546.3 \text { 전기설비 }}$ \\
546.5 증기(스팀) 파이프 기구 \\
546.6 온수파이프 및 기구 \\
546.8 소방설비 \\
546.9 기타 건축설비
\end{tabular} & $\begin{array}{l}546 \text { 건축 환경, 설비, 배관 및 } \\
\text { 파이프 부설 } \\
546.1 \text { 건축환경 } \\
\underline{546.2 \text { 급배수설비 }} \\
\frac{546.3 \text { 가스설비 }}{546.4 \text { 전기설비 }} \\
546.5 \text { 증기(스팀) 파이프, 기구 } \\
546.6 \text { 온수파이프 및 기구 } \\
546.8 \text { 소방설비 } \\
546.9 \text { 기타 건축설비 }\end{array}$ \\
\hline
\end{tabular}




\begin{tabular}{|c|c|c|c|}
\hline KDC 5판(2009) & KDC 6판(2013) & KDC 5판(2009) & KDC 6판(2013) \\
\hline $\begin{array}{l}541 \text { 건축재료 } \\
541.1 \text { 목재 } \\
541.2 \text { 석재 } \\
541.3 \text { 콘크리트 및 철근콘크 } \\
\text { 리트 } \\
541.4 \text { 요업제 및 점토재 } \\
541.5 \text { 시멘트 } \\
541.6 \text { 유리 } \\
541.7 \text { 철 및 강철구조 } \\
541.8 \text { 기타 건축용 금속재 } \\
541.9 \text { 기타 건축재료 }\end{array}$ & \begin{tabular}{|l}
541 건축재료 \\
541.1 목재 \\
541.2 석재 \\
541.3 콘크리트 및 철근콘크리트 \\
541.4 요업제 및 점토재 \\
541.5 시멘트 \\
541.6 유리 \\
541.7 철 및 강철구조 \\
541.8 기타 건축용 금속재 \\
541.9 기타건축재료
\end{tabular} & $\begin{array}{l}547 \text { 난방, 환기 및 공기조화공학 } \\
547.1 \text { 방열성 부분난방 } \\
547.2 \text { 공기난방 } \\
547.3 \text { 온풍난방 } \\
547.4 \text { 온수난방 및 배관작업 } \\
547.5 \text { 증기(스팀)난방 } \\
\\
547.7 \text { 기타 난방방법 } \\
547.8 \text { 환기 및 공기조화 }\end{array}$ & $\begin{array}{l}547 \text { 난방, 환기 및 공기조화 공학 } \\
547.1 \text { 방열성 부분난방 } \\
547.2 \text { 공기난방 } \\
547.3 \text { 온풍난방 } \\
547.4 \text { 온수난방 및 배관작업 } \\
547.5 \text { 증기(스팀)난방 } \\
\\
547.7 \text { 기타 난방방법 } \\
547.8 \text { 환기 및 공기조화 }\end{array}$ \\
\hline $\begin{array}{l}542 \text { 건축실무 } \\
542.1 \text { 건축설계 } \\
542.2 \text { 건축제도 } \\
542.3 \text { 설계서 } \\
542.4 \text { 입찰 및 계약사무 } \\
542.5 \text { 노동, 시간, 재료의 견적 } \\
\quad \text { 및 건축비 } \\
542.6 \text { 감리 } \\
542.8 \text { 건축시공, 공사 } \\
542.9 \text { 기타 건축실무 }\end{array}$ & $\begin{array}{l}542.4 \text { 입찰 및 계약사무 } \\
542.5 \text { 노동, 시간, 재료의 견적 } \\
\quad \text { 및 건축비 } \\
542.6 \text { 감리 } \\
542.8 \text { 건축시공, 공사 } \\
542.9 \text { 기타건축시공 }\end{array}$ & $\begin{array}{l}548 \text { 건축마감 } \\
548.1 \text { 도장작업 } \\
548.2 \text { 수성도료(도장) } \\
548.3 \text { 목재의 마감손질 } \\
548.5 \text { 유리세공 } \\
548.6 \text { 도배 } \\
548.8 \text { 바닥마감 }\end{array}$ & $\begin{array}{l}548 \text { 건축마감 및 인테리어 } \\
548.1 \text { 도장작업 } \\
548.2 \text { 수성도료(도장) } \\
548.3 \text { 목재의 마감손질 } \\
548.5 \text { 유리세공 } \\
548.6 \text { 도배 } \\
548.8 \text { 바닥마감 } \\
548.9 \text { 인테리어 } \\
\end{array}$ \\
\hline $\begin{array}{l}543 \text { 건축구조의 유형 } \\
543.1 \text { 기초공학(토질) } \\
543.2 \text { 석재구조 } \\
543.3 \text { 벽돌구조 } \\
543.4 \text { 목구조 } \\
543.5 \text { 타일 및 테라코타 구조 } \\
543.6 \text { 블록구조 } \\
543.7 \text { 콘크리트 및 철근콘크리 } \\
\text { 트 구조 } \\
543.8 \text { 철골구조 } \\
543.9 \text { 기타 재료의 건축 }\end{array}$ & $\begin{array}{l}543 \text { 구조역학 및 건축일반구조 } \\
543.1 \text { 구조역학 } \\
543.2 \text { 석재구조 } \\
543.3 \text { 벽돌구조 } \\
543.4 \text { 목구조 } \\
543.5 \text { 타일 및 테라코타 구조 } \\
543.6 \text { 블록구조 } \\
543.7 \text { 콘크리트 및 철근콘크리트 } \\
\text { 구조 } \\
543.8 \text { 철골구조 } \\
543.9 \text { 기타 재료의 건축 }\end{array}$ & 549 각종 건물 & $\begin{array}{l}549 \text { 각종 건물 } \\
\frac{549.1 \text { 궁전, 성곽 }}{549.2 \text { 종교건물 }} \\
\frac{549.3 \text { 공공건물 }}{549.4 \text { 과학 및 연구용 건물 }} \\
\frac{549.5 \text { 공업용건물 }}{549.6 \text { 상업, 교통, 통신용 건물 }} \\
\frac{549.7 \text { 주거용건물 }}{549.8 \text { 기타 건물 }}\end{array}$ \\
\hline $\begin{array}{l}544 \text { 친환경건축 } \\
544.1 \text { 설계 및 재료 } \\
544.2 \text { 공법 } \\
544.3 \text { 유지관리 } \\
544.4 \text { 경제성 }\end{array}$ & 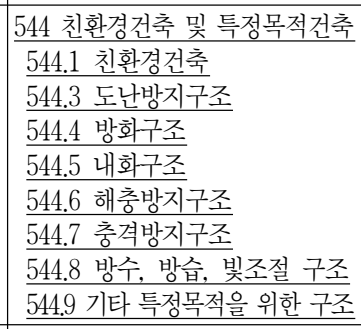 & $\begin{array}{l}610 \text { 건축술(建築術) } \\
610.9 \text { 건축사 }\end{array}$ & $\begin{array}{l}549 \text { 각종건물 } \\
540.09 \text { 건축사 }\end{array}$ \\
\hline $\begin{array}{l}545 \text { 건물 세부구조 } \\
545.1 \text { 벽체 } \\
545.2 \text { 기둥 } \\
545.3 \text { 지붕 } \\
545.4 \text { 천장 } \\
545.5 \text { 바닥 } \\
545.6 \text { 곡선구조 } \\
545.7 \text { 기타 건축요소 } \\
545.8 \text { 동양식세부구조 } \\
545.9 \text { 서양식 세부구조 }\end{array}$ & $\begin{array}{l}545 \text { 건물 세부구조 } \\
545.1 \text { 벽체 } \\
545.2 \text { 기둥 } \\
545.3 \text { 지붕 } \\
545.4 \text { 천장 } \\
545.5 \text { 바닥 } \\
545.6 \text { 곡선구조 } \\
545.7 \text { 기타 건축요소 } \\
545.8 \text { 동양식세부구조 } \\
545.9 \text { 서양식세부구조 }\end{array}$ & $\begin{array}{l}611 \text { 궁전, [묘사], 성곽 } \\
612 \text { 종교건물 } \\
613 \text { 공공건물 } \\
614 \text { 과학 및 연구용건물 } \\
615 \text { 공업용건물 } \\
616 \text { 상업, 교통, 통신용건물 } \\
617 \text { 주거용 건물 } \\
618 \text { 기타 건물 } \\
619 \text { 장식 및 의장 }\end{array}$ & $\begin{array}{l}\frac{549.1 \text { 궁전, 성곽 }}{549.2 \text { 종교건물 }} \\
\frac{549.3 \text { 공공건물 }}{549.4 \text { 과학 및 연구용 건물 }} \\
549.5 \text { 공업용건물 } \\
549.6 \text { 상업, 교통, 통신용 건물 } \\
549.7 \text { 주거용건물 } \\
549.8 \text { 기타 건물 } \\
548.9 \text { 인테리어 } \\
\end{array}$ \\
\hline
\end{tabular}

* KDC 5 판의 굵은 글씨는 다른 곳으로 이동한 항목이며, 밑줄은 명칭이 변경된 부분임.

** $\mathrm{KDC} 6$ 판의 밑줄은 5 판과 항목이 달라진 부분임. 
548은 '건축마감'에서 '건축마감 및 인테리 어'로 바뀌었다. 548.9 에에는 5 판의 619 에 분류 되었던 '장식 및 의장'이 '인테리어’로 항목명이 바뀌어 이동되었다.

549 '각종 건물'은 전체 항목 중 가장 변화가 큰 부분이다. 〈표 4 〉와 같이 5 판의 610 '건축술' 은 하위에 목적별 건물과 구조를 놓았으나, 6 판 에서 강(綱)을 통합하면서 610 '건축술' 아래의 건축물 관련 문헌 분류는 모두 549 아래로 이동 했다. 549 의 항목명은 6 판에서도 변하지 않았으 며, 원래 세목이 없었기 때문에 611 '궁전, [묘 사], 성곽'은 549.1로, 612 '종교건물'은 594.2로, 613 '공공건물'은 549.3으로 이동하는 등 611부 터 618 까지의 항목이 549.1에서 549.8로 이동하 였다. 다만 619 '장식 및 의장'은 앞서 언급한 것 처럼 548.9의 '인테리어'로 이동하였다.

549 '각종 건물'의 세목 이하를 살펴보면, $\mathrm{KDC}$ 5판 613.7 '교육용 건물'은 6판에서 549.37로 이동하며 항목명에 연구용 건물이 추가되었다. 그런데 594.4에도 '과학 및 연구용 건물'이 있 어 혼란스러운 부분이 있다. 그리고 $\mathrm{KDC} 5$ 판 의 618 '기타 건물' 아래에 분류되던 묘지와 화 장장은 6 판에서 549.6 '상업, 교통, 통신용 건 물' 아래로 이동하여 각각 594.68과 594.69로 변 경되었다. 이러한 분류 이동은 묘지나 화장장이 최근에는 상업적 성격까지 갖게 되었기 때문 이다.

또 다른 중요한 변경은 $\mathrm{KDC} 5$ 판 610.9 '건축 사'의 항목 이동 및 전개이다. 6 판에서는 540.09 로 이동했으며 원시, 고대, 중세, 근세 등 시대 별 구분만 가능했던 5 판과는 달리, 동서양의 건축사 모두 지역구분을 추가할 수 있게 되 었다.

\section{2 $\mathrm{DDC}$ 23판과 $\mathrm{KDC}$ 6판의 비교}

$\mathrm{KDC}$ 의 건축학 분야는 $\mathrm{DDC}$ 의 항목을 번역 하여 그대로 사용한 부분이 많아서 $\mathrm{KDC} 5$ 판 까지는 $\mathrm{DDC}$ 와 유사한 구조로 전개되었으며 항목도 비슷한 것이 많았다. 그러나 $\mathrm{KDC}$ 6판 은 〈표 5 〉와 같이 DDC 23 판과 다른 전개를 하 고 있다.

$\mathrm{KDC}$ 의 540 '건축, 건축학'은 $\mathrm{DDC}$ 의 690 'Construction of buildings'에 해당하지만 분류표 에 나타난 항목명을 비교하면 상당히 다르다. $\mathrm{KDC}$ 6판의 540.1은 6판에서는 '건축계획(Architect's planning and design)'으로 이에 대응하는 DDC 의 690.1 '구조적 요소(Structural elements)'와 항목명이 눈에 띄게 달라졌다. 그러나 541 '건 축재료'는 $\mathrm{KDC}$ 6판과 $\mathrm{DDC} 23$ 판이 유사하게 전 개되었다. DDC 23 판의 690.2 '건축활동(General activities of buildings)'은 $\mathrm{KDC} 6$ 판의 542.1 '건축활동'에 해당하여 항목의 구조가 다름을 보 여준다. 또한 542 '건축실무'의 세목 중 '입찰 및 계약사무'와 '감리'는 $\mathrm{DDC}$ 의 세목에는 없으며, DDC 692.1 '설계와 도면(Plans and drawings)' 항목에 대응하는 542.1 의 '건축설계', 542.2 의 '건 축제도'는 모두 540.1 의 '건축계획' 아래로 이동 했다.

$\mathrm{KDC}$ 의 543은 '구조역학 및 건축일반구조' 로, DDC 693의 '건축재료나 목적에 따른 구분 (Construction in specific types of materials and for specific purpose)'과는 순서차이는 있 으나 대체적으로 대응이 가능하다. 다만 이 중 $\mathrm{DDC}$ 693.8의 '특정 목적 건축(Construction for specific purpose)'은 $\mathrm{KDC}$ 6판에서 544에 포함되었다. 
〈표 5〉 DDC 23판, $\mathrm{UDC}$ 표준 3판, $\mathrm{NDC}$ 9판, $\mathrm{KDC} 5$ 판, $\mathrm{KDC}$ 6판의 건축학 분야 비교

\begin{tabular}{|c|c|c|c|c|c|c|c|c|c|}
\hline \multicolumn{2}{|r|}{$\mathrm{DDC}$ 23판(2011) } & \multicolumn{2}{|c|}{ UDC 표준 3판(2005) } & \multicolumn{2}{|c|}{ NDC 신정9판(1995) } & \multicolumn{2}{|c|}{ KDC 5판(2009) } & \multicolumn{2}{|c|}{ KDC 6판(2013) } \\
\hline 690 & $\begin{array}{l}\text { Construction of } \\
\text { buildings }\end{array}$ & 69 & $\begin{array}{l}\text { Building(Construction) } \\
\text { Trade }\end{array}$ & 520 & 건축학 & 540 & 건축공학 & 540 & $\begin{array}{l}\text { 건축(建築), } \\
\text { 건축학(建築學) }\end{array}$ \\
\hline 691 & Building materials & 691 & Building Materials & 521 & 일본의 건축 & 541 & 건축재료 & 541 & 건축재료 \\
\hline 692 & $\begin{array}{l}\text { Auxiliary } \\
\text { construction practices }\end{array}$ & 692 & $\begin{array}{l}\text { Structural parts and } \\
\text { elements of buildings }\end{array}$ & 522 & $\begin{array}{l}\text { 동양의 건축. } \\
\text { 아시아의 건축 }\end{array}$ & 542 & 건축실무 & 542 & 건축 시공 및 적산 \\
\hline 693 & $\begin{array}{l}\text { Construction in } \\
\text { specific types of } \\
\text { materials and for } \\
\text { specific purpose }\end{array}$ & 693 & $\begin{array}{l}\text { Masonry and related } \\
\text { building craft }\end{array}$ & 523 & $\begin{array}{l}\text { 서양의 건축. 그외의 } \\
\text { 양식 건축 }\end{array}$ & 543 & 건축구조의 유형 & 543 & $\begin{array}{l}\text { 구조역학 및 } \\
\text { 건축일반구조 }\end{array}$ \\
\hline 694 & Wood construction & 694 & Timber construction & 524 & 건축구조 & 544 & 친환경건축 & 544 & $\begin{array}{l}\text { 친환경건축 및 } \\
\text { 특정목적건축 }\end{array}$ \\
\hline 695 & Roof covering & & & 525 & 건축계획.시공 & 545 & 건물 세부구조 & 545 & 건물 세부구조 \\
\hline 696 & Utilities & 696 & $\begin{array}{l}\text { Equipments, Services, } \\
\text { Installations in } \\
\text { buildings }\end{array}$ & 526 & 각종의 건축 & 546 & $\begin{array}{l}\text { 건축설비, 배관 및 } \\
\text { 파이프의 부설 }\end{array}$ & 546 & $\begin{array}{l}\text { 건축 환경, 설비, 배관 } \\
\text { 및 파이프 부설 }\end{array}$ \\
\hline 697 & $\begin{array}{l}\text { Heating, ventilating, } \\
\text { air-conditioning } \\
\text { engineering }\end{array}$ & 697 & $\begin{array}{l}\text { Heating, Ventilation } \\
\text { and air conditioning of } \\
\text { buildings }\end{array}$ & 527 & 주택건축 & 547 & $\begin{array}{l}\text { 난방, 환기 및 } \\
\text { 공기조화공학 }\end{array}$ & 547 & $\begin{array}{l}\text { 난방, 환기 및 } \\
\text { 공기조화 공학 }\end{array}$ \\
\hline \multirow[t]{2}{*}{698} & Detail finishing & 698 & $\begin{array}{l}\text { Finishing and } \\
\text { decoration trades }\end{array}$ & 528 & 건축설비·설비공학 & 548 & 건축마감 & 548 & $\begin{array}{l}\text { 건축마감 및 } \\
\text { 인테리어 }\end{array}$ \\
\hline & & & & 529 & 건축의장 $\cdot$ 장식 & 549 & 각종 건물 & 549 & 각종 건물 \\
\hline 720 & Architecture & 720 & Architecture & & & 610 & 건축술(建築術) & & \\
\hline 721 & $\begin{array}{l}\text { Architectural } \\
\text { materials and } \\
\text { structural elements }\end{array}$ & 721 & Buildings generally & & & 611 & 궁전, [묘사], 성곽 & 549.1 & 궁전, 성곽 \\
\hline 722 & $\begin{array}{l}\text { Architecture from } \\
\text { earliest times to ca. } 300\end{array}$ & & & & & 612 & 종교건물 & 549.2 & 종교건물 \\
\hline 723 & $\begin{array}{l}\text { Architecture from } \\
\text { ca.300 to } 1399\end{array}$ & & & & & 613 & 공공건물 & 549.3 & 공공건물 \\
\hline 724 & $\begin{array}{l}\text { Architecture from } \\
1400\end{array}$ & & & & & 614 & $\begin{array}{l}\text { 과학 및 } \\
\text { 연구용건물 }\end{array}$ & 549.4 & 과학 및 연구용건물 \\
\hline 725 & Public structures & 725 & $\begin{array}{l}\text { Public, Civil, } \\
\text { Commercial, Industrial } \\
\text { buildings }\end{array}$ & & & 615 & 공업용건물 & 549.5 & 공업용건물 \\
\hline 726 & $\begin{array}{l}\text { Buildings for religious } \\
\text { and related purposes }\end{array}$ & 726 & $\begin{array}{l}\text { Religious Ecclesiastical } \\
\text { architecture }\end{array}$ & & & 616 & $\begin{array}{l}\text { 상업, 교통, } \\
\text { 통신용건물 }\end{array}$ & 549.6 & $\begin{array}{l}\text { 상업, 교통, } \\
\text { 통신용건물 }\end{array}$ \\
\hline 727 & $\begin{array}{l}\text { Buildings for } \\
\text { educational and } \\
\text { research purposes }\end{array}$ & 727 & $\begin{array}{l}\text { Buildings for } \\
\text { educational scientific, } \\
\text { cultural purposes }\end{array}$ & & & 617 & 주거용 건물 & 549.7 & 주거용 건물 \\
\hline 728 & $\begin{array}{l}\text { Residential and } \\
\text { related buildings }\end{array}$ & 728 & Domestic architecture & & & 618 & 기타 건물 & 549.8 & 기타 건물 \\
\hline 729 & $\begin{array}{l}\text { Design and decoration } \\
\text { of structures and } \\
\text { accessories }\end{array}$ & 729 & & & & 619 & 장식 및 의장 & 548.9 & 인테리어 \\
\hline
\end{tabular}

* 굵은 글씨는 $\mathrm{KDC}$ 에 완벽하게 대응하는 항목이 없는 것임. 
544 는 $\mathrm{KDC} 6$ 판과 $\mathrm{DDC} 23$ 판이 가장 차이나 는 부분으로 $\mathrm{DDC}$ 에서는 694 에 목공과 대목 (Carpentry)을 포함한 '목건축(Wood construction)'으로 다루고 있으나, $\mathrm{KDC}$ 는 5판부터 543 의 하부에 분류되어 건축 재료에 따른 구분 아 래에 놓았다. 대신 $\mathrm{KDC}$ 는 544 에 건축의 신조 류를 나타내는 친환경건축을 삽입했으며, 6 판 에서는 도난방지나 방화 등 다양한 목적의 건 축을 544 에 함께 분류하고 있다.

545 도 $\mathrm{KDC}$ 와 $\mathrm{DDC}$ 의 차이가 두드러지는 부 분인데, DDC 695는 지붕마감(Roof covering) 이지만 $\mathrm{KDC}$ 에서는 지붕을 포함하여 벽체, 기둥, 천장, 바닥 등의 건물 세부구조를 이곳에 분류 하고 있으며, $\mathrm{DDC}$ 는 지붕을 제외한 구조의 경 우 721 '건축재료 및 구조적 요소(Architectural materials and structural elements)' 아래에 분류하고 있다.

546 은 건축 환경, 설비, 배관 및 파이프 부설이 란 항목명을 사용하여 DDC의 696 설비(Utilities) 와 달라 보이지만 세목이 급배수 설비나 가스 설비 등의 설비를 다루고 있다는 점에서 유사 하다. 다만 5 판과 달리 6 판에서는 546.1에 '건축 환경'을 신설하였으며, 이는 $\mathrm{DDC}$ 에 없는 항목 이다. 또한 $\mathrm{DDC}$ 는 '상수도설비(Plumbing)'와 '배관공사(Pipe fitting)'를 분리하여 별도의 항 목으로 두었으나 $\mathrm{KDC}$ 는 급배수설비와 가스설 비 등 설비의 종류로만 분리하고 있다는 점도 다르다. 그리고 전기설비는 $\mathrm{DDC}$ 의 건축학 아 래가 아니라 DDC 621.3의 '전기학' 아래, 소방 설비는 DDC 628.92 '소방공학' (위생공학 하부 주제) 아래에 분류된다. 즉, $\mathrm{KDC} 4$ 판 540 건축 공학에 대한 윤춘섭(1999)의 지적처럼 $\mathrm{DDC}$ 에 서는 일부 건축공학 설비가 건축학 분야가 아
닌 관련 분야로 문헌이 분산되는 문제가 발생 할 수 있다.

547 '난방, 환기 및 공기조화 공학'은 $\mathrm{DDC}$ 의 697 '난방, 환기 및 공기조화 공학(Heating, ventilating, air-conditioning engineering)'과 항목명이 동일하다. 다만 $\mathrm{DDC}$ 에서는 697.8 에 '굴뚝과 연통'을, 697.9 에 '특정 종류의 건물에 대한 난방 환기 및 공기조화 공학'을 분류하도 록 하였다. $\mathrm{KDC} 6$ 판에서는 굴뚝과 연통(연도) 는 547.07 '난방설비'의 포함 주기에 있다.

548 '건축마감은 DDC의 698 'Detail finishing' 과 거의 동일한 내용을 다루고 있으나, $\mathrm{KDC} 6$ 판 의 548.9 '인테리어' 항목에서 차이가 난다. 5 판 은 DDC 698과 동일한 구조를 갖고 있으나 6판 에서 610 '건축술'을 통합하면서 619 의 '장식 및 의장'이 548.9의 '인테리어'로 이동되었다.

549 '각종 건물'에 대한 $\mathrm{DDC}$ 와의 비교 분석 은 $\mathrm{DDC} 720$ 과 비교해야 한다. $\mathrm{KDC} 5$ 판의 610 '건축술'과 DDC 720 의 '건축(Architecture)'은 같은 예술(Art) 아래 분류되어 있지만 전개 방 향은 사뭇 다르다. 5 판의 610 '건축술'은 건축 완성품이라 할 수 있는 건물을 용도별로 구분하 여 611부터 618까지 전개했고, 619에는 그 장식 과 의장을 다루었다. 그러나 DDC의 720 은 721 부터 729에 '건축의 특정 양상(Specific aspects of architecture)'을 다루었으며 721에는 그 중 에서도 건축의 부분적 요소들인 벽체, 기둥, 지 붕, 마루 등을 다루었다. KDC 5판에서는 545 '건물 세부구조' 아래 전개되었으며, 이는 6 판에 서도 동일하다.

DDC 722 부터 724 까지는 시대별로 건축물을 세분하였으며, 725 부터 728 은 특정 종류의 건물, 729 는 장식 및 의장을 다루었다. 722 에서는 고 
대의 건축물을 다루면서 지역별로 세분하였으 므로 동아시아나 이집트, 중동, 로마, 그리스 등 의 고대 건축물을 분류하기 용이하다. $\mathrm{KDC} 6$ 판 에서는 건물의 종류별로 구분하는 방법 밖에 없 으므로 고대 이집트의 종교시설과 공공시설을 함께 다룬 문헌처럼 시대별로 건축물을 다룬 도 서는 상위 분류인 549 각종 건물에 분류해야 한 다. 건축사에 분류하는 방법도 고려할 수 있으 나, 540.09 아래에 전개된 각 시대의 건축사는 분류번호가 상당히 길어진다는 단점이 있다. 고 딕건축의 경우, 5 판에서는 610.92035 에 분류하 였으나 6판에서는 540.092035로 한 자리 늘어 났다. 그러므로 분류기호의 단순성, 간결성을 살리면서 주제를 어떻게 해야 최대한 완벽하게 표현할 수 있을지에 대한 모색이 필요하다.

\subsection{NDC 신정9판과 $\mathrm{KDC}$ 6판의 비교}

〈표 5〉와 같이 NDC는 500 기술과학 아래에 520 '건축학(Architecture, Building)'을 두었 으며, 영문명에서 보이듯이 건축공학과 건축물 을 한 곳에 모아 분류하였다. 그러나 $\mathrm{KDC} 6$ 판 의 구조와는 달리, 521-523에는 국가별 건축을 전개하고 그 뒤에 524 '건축구조', 525 '건축계 획, 시공', 528 '건축설비, 설비공학'을 놓고 526 에는 '각종의 건축', 529 에 '건축의장장식'을 놓 고 있어 건축공학과 건축술이 섞여 있다.

520 '건축학'의 바로 아래에는 520.7에 연구법, 지도법 등을 넣고 있어 조기표를 적용한 $\mathrm{KDC}$ 와 비슷한 것 같지만, 520.9 에 주택산업을 함께 분류 한다는 지시사항과 함께 '건축업'이 있다. $\mathrm{KDC}$ 6판에서는 542.1 '건축활동' 아래에 '건축업의 면 허와 등록절차를 포함한다.'는 포함주기를 넣고
있다.

$\mathrm{KDC}$ 가 건축학의 첫 번째 목인 541과 691에 '건축재료'를 넣고 있는데 반해, NDC는 521에 '일본의 건축'을 전개하였으며 그 아래에 시대 별 구분을 삽입하였다. 522 는 '동양의 건축'이며 523 은 '서양의 건축'으로 건축물을 건축학 앞부 분에 배치했다는 점이 독특하다. 또한 '일본의 건축'은 세목에서 시대 구분을 하고 있는데 반 해, '동양의 건축물'과 '서양의 건축물'은 세목 에서 지리 구분이 가능하다는 주기를 달아 놓았 다. 일본의 건축물 중에서도 중요 문화재로 지 정된 건축물은 시대 구분과는 별도로 세목을 삽 입하여, 521.8 에 '각종의 일본건축. 국보 · 중요 문화재의 건축물'로 분류하고 있다는 점도 대표 적인 건축물에 큰 의미를 부여했음을 알 수 있 다. 522 '동양의 건축물'에서는 522.1에 한국을 놓고 522.2 에 중국을 놓았다는 점도 $\mathrm{KDC}$ 의 지 리구분과는 다르게 전개되는 부분이다.

$\mathrm{NDC}$ 의 건축 역학은 524 '건축구조'부터 전개 된다. 건축구조에서는 세목으로 '구조공학', '건 축재료', '기초', '블록구조'를 전개하고 그 뒤에 524.5 에서 524.7 까지 '목구조', '철골구조', '철근 콘크리트 구조' 등 재료에 따른 건축구조를 다루 었다. 524.8은 '각부구조'를, 524.9에는 '방재구조' 를 다루고 있어 543 '구조역학 및 건축일반구조' 에서 건축 구조의 종류를, 545 의 '건물 세부구 조'에서 각부구조를 다루고, 544 '친환경건축 및 특정목적건축'에서 방재구조를 분리하여 다루 는 $\mathrm{KDC}$ 보다 훨씬 간략하게 다루고 있다.

525 는 건축계획, 시공을 다루고 있는데, 이는 $\mathrm{KDC} 542$ 의 '건축 시공 및 적산'과 유사한 내용 을 전개하고 있다. 다만 525.1 '건축계획 - 설계' 뒤에 나오는 525.2 '규구술(規矩術)'은 $\mathrm{KDC}$ 를 
포함한 다른 십진분류법에는 없는 독특한 항목 이다. 규구술은 건축자재를 가공할 때 곡척이라 는 옛 단위로 처리하는 방법을 나타내는 것으로 $\mathrm{NDC}$ 에서는 일본 전통 가옥과 관련된 내용을 별 도 항목으로 다루고 있음을 나타낸다. 525의 세 목은 '건축계획 - 설계', '규구술', '사양, 적산, 건 축비', '건축공사, 가공각론', '시공기계', '건물의 유지 - 관리'의 순으로 전개되어 입찰, 견적 및 건 축비, 감리, 건축 시공 공사, 기타 건축시공의 순 으로 전개되는 $\mathrm{KDC}$ 와는 조금 다르다. $\mathrm{NDC}$ 에는 감리가 빠지는 대신 건물의 유지 - 관리가 추가 되었으며 $\mathrm{KDC}$ 에서 건물의 유지 · 관리는 주거 학 쪽에 분류하고 있다.

526 은 각종 건물을 분류하며, 역사적 건축물 은 521 에 분류하고 여기에는 현대 건축물을 분류 하도록 하였다. 주기에 강목표(본표)를 이용하 여 분류하라고 기술했으며, 예시로 박물관(.06), 신문사(.07), 사원(.18), 관공서(.31), 학교 대학 (.37) 등을 기술하여 본표의 목에 해당하는 주제 와 관련된 건물을 세분 전개하도록 지시하고 있 다. KDC 6 판의 549 는 종류에 따라 분류하고 본 표는 사용하지 않는다는 점에서 $\mathrm{NDC}$ 와 다르다. 또 일본의 건축물만 시대구분을 하고 동양과 서 양의 건축물은 지리 구분외의 특별한 지시사항 이 없다는 점도 $\mathrm{KDC}$ 와는 다르다.

527 주택 건축은 $\mathrm{KDC} 545$ 의 건물 세부구조 와 비슷하게 전개할 것 같으나, 실제 내용은 전 혀 다르다. NDC 527은 주택의 각 부분을 상술 하고 있으며 527.1부터 527.6까지는 주택의 각 구성요소에 대한 세목을 나열했다. 527.1은 '설 계, 부지, 방 배치’이며, 527.2는 '현관과 큰방, 복도, 계단', 527.3은 '부엌, 식당, 다용도실’을 다 룬다. 이처럼 앞에서는 주택의 세부 구조를 다
루고 그 뒤의 527.7 부터 527.9 까지는 방갈로, 집 합 주택, 기숙사를 전개하였다. $\mathrm{KDC}$ 에서는 주 택의 세부구조를 549.7 '주거용건물' 아래에서 전개했으며, 595.3 '주택관리 및 가정설비'에서 도 이와 유사한 내용을 다루고 있다.

528 은 건축설비와 설비공학이며 $\mathrm{KDC} 546$ 의 '건축 환경, 설비, 배관 및 파이프 부설'과 유사하 다. 하지만 $\mathrm{KDC}$ 가 급배수설비, 가스설비, 전기 설비, 증기파이프, 온수파이프, 소방설비 순으로 전개하고 있는 반면 $\mathrm{NDC}$ 는 위생설비, 공기조화 (난방, 냉방), 굴뚝 연통, 에너지 설비, 기계운반 설비, 소방설비, 주방설비 순으로 전개하고 있다. 529 는 건축의장 장식으로 $\mathrm{KDC} 6$ 판의 548.9 에 해당하나 그 아래의 세목은 없다.

\subsection{UDC 표준 3판과 $\mathrm{KDC}$ 6판의 비교}

〈표 5〉와 같이 UDC 본표의 전체적인 구조 는 $\mathrm{DDC}$ 와 유사하기 때문에 $\mathrm{DDC}$ 와 $\mathrm{UDC}$ 를 비 교한 뒤 차이나는 부분을 뽑아 $\mathrm{KDC}$ 와 추가로 비교하였다.

$\mathrm{UDC}$ 의 691은 $\mathrm{DDC}$ 와 마찬가지로 건축재료 (Building material)를 다루고 있는데, 이 중 691.8은 '간단한 장치와 도귀(Simple units. Builders' hardware)'를 다루고 있다. DDC나 KDC에서 는 세목 이하에 등장하거나 없는 내용인데, 이 것이 건축 장치나 도구를 의미하는 것이 아니 라 더 넓은 의미에서 건물을 구성하는 단위도 포함하는 것임을 감안하면 $\mathrm{KDC}$ 에 추가할 필 요가 있다. 특히 최근 들어 공간을 하나의 단위 로 보고 이를 공장에서 각 단위별로 생산하고 결합시켜 주택을 조립 건축하는 방식도 새로 도입되고 있으므로 충분히 세목으로 둘만한 가 
치가 있다.

UDC 692 '건물의 구조와 요소(Structural parts and elements of buildings)'는 DDC의 721 '건축 재료와 구조적 요소(Architectural materials and structural elements)'에 해당한 다. $\mathrm{DDC}$ 는 692 에서 건축실무를 다루며 $\mathrm{KDC}$ 에서는 542 '건축시공 및 적산'에 해당하지만 $\mathrm{UDC}$ 에 대응하는 강목은 없다.

693 '석조건축(Masonry and related building craft)'은 DDC와 유사하나 694의 '목조건축 (Timber construction. carpentry. joinery)'은 다른 양상을 보인다. UDC는 그 아래 세목을 694.3의 '임시 목구조(Temporary timber construction)', '튼튼한 목구조(Heavy timber construction)'와 '가벼운 목구조(Light timber construction)' 등 구조의 형태에 따라 전개했 다. $\mathrm{DDC}$ 는 목조건축의 구조를 짜는 대목(Carpentry) 과 장식을 하는 소목(Joinery)으로만 크 게 나누고 있으며 UDC처럼 목구조를 세목에서 전개하지 않았다.

UDC 696의 설비는 DDC 696과 비슷한 수준 으로 전개하여 배관, 증기배관, 온수공급을 전 개하였으며, $\mathrm{KDC}$ 에서처럼 전기설비도 함께 전 개했다. 그 뒤 696.5에는 $\mathrm{KDC}$ 나 $\mathrm{DDC}$ 에는 없 는 '압축공기(Pneumatic, compressed air and vacuum installation)'에 대한 항목을 넣고 있 다. 697 '난방(Heating, Ventilation and air conditioning of buildings)' 부분은 DDC와 항 목 순서의 차이는 있으나 대체적으로 개별난방, 중앙난방과 온수난방, 증기난방 등 난방 방식 에 따라 전개하고 있다. 698 은 마감 및 장식을 다루고 있으며 $\mathrm{DDC}$ 와 크게 차이나지 않는다. 건축물을 다루는 72 Architecture는 DDC나
$\mathrm{KDC}$ 와는 다른 특징적인 모습을 보인다. $\mathrm{KDC}$ 5 판에서는 610 에 목적 등에 따른 다양한 건물 을 분류하였으며 이는 KDC 6 판의 549 로 이동 하였다. $\mathrm{DDC}$ 는 721 에서 건물 구조를 다루고 722-724는 시대별 건축물, 725-728에서 목적에 따른 건축물을 다루고 있다. UDC는 721-724의 항목이 없으며, 725에는 $\mathrm{KDC}$ 의 549.3-549.7에 해 당하는 공공건물, 상업건물(Public, Civil, Commercial, Industrial buildings)을 넣었다. 대신 725 의 항목 뒤에는 본표의 분류기호를 덧붙여 구체적인 공공기관이나 은행 등의 각종 건물들 을 폭넓게 전개할 수 있다. 726 은 종교건물, 727 은 교육, 학문, 문화 목적의 건물, 728 은 주거용 건물을 분류한다. 729 는 공기호이며, DDC 729 의 인테리어 부분은 698 로 분류한다.

\section{5 시사점 및 개선안}

$\mathrm{KDC} 5$ 판, $\mathrm{KDC} 6$ 판과 주요십진분류표의 건 축학은 분류 전개 방식이 같은 부분과 다른 부분 이 있는데, 그 차이점을 정리하면 다음과 같다. 첫째, $\mathrm{KDC} 5$ 판과 $\mathrm{DDC}$ 는 건축공학과 건축 물을 분리하여 다루고 있다. 이는 건축물을 만 드는 과정의 여러 공학적이고 기술적인 측면과 건축물 자체의 예술적인 측면을 분리하여 보는 건축에서 유래한 것이다.

둘째, $\mathrm{NDC}$ 신정9판과 $\mathrm{KDC}$ 6판은 건축학을 기술과학 아래 통합하여 분류하고 있다. 이는 건축공학 또는 건축물과 관련된 문헌을 이용하 는 사람들이 건축공학과 건축물에 관한 자료를 함께 참고하는데 근거한다.

셋째, $\mathrm{KDC} 5$ 판과 6 판의 건축학은 상당한 부 분에서 차이를 보인다. $\mathrm{DDC}$ 의 전개방식을 따 
랐던 5 판과는 달리 6 판에서는 예술분야의 건 축물 관련 항목을 540 에 흡수 통합하였다. 그 렇기 때문에 이용자의 편의를 위해 건축학의 예술적 요소보다는 기술 측면을 강조하여 건축 학의 학문적 구조를 통합하였다는 지적을 받을 수 있다.

넷째, NDC 신정9판은 자국의 건축을 목(division) 수준에서 전개했다. 한국의 건축물은 6판 에서는 549 의 각종 건물 아래에 세목으로 세구 분하여 전개하거나 540.09 '건축사' 아래에 전개 하므로 분류기호가 지나치게 길어지는 문제가 발생한다. 그 결과, 이용자들에게 가독성이나 인식성이 떨어질 가능성이 높다. 또한 $\mathrm{NDC}$ 에 서는 규구술 등 여러 세목에서 자국의 건축학적 특성을 반영하고 있으나, $\mathrm{KDC}$ 는 일반적인 수 준에서 건축학을 다루고 있고, $\mathrm{DDC}$ 의 전개 방 식에 의존도가 높은 편이다.

이에 대한 개선방안으로 〈표 6)과 같이 현재 540.09 에 전개되는 '건축사' 항목을 540.9 로 한 단계 올려 전개하는 것을 제안한다. 여지숙, 공 성훈, 오동근(2013)은 요목 단계에서는 540 '건 축학' 바로 아래인 540.9에 '건축사를 놓았다. 그 러나 세목단계의 수정에서 541 의 건축계획에 앞 서 고려해야하는 공간론, 건축심리, 건축색채 등 의 건축학 관련 이론을 추가 전개하기 위해 540.1 에 건축계획을 신설하였다. 이를 반영하기 위해 $\mathrm{KDC} 6$ 판에서는 540 아래 '540.01-.09는 표준구 분에 따라 세분한다.'는 주기를 넣고 540.09 에 건축사를 분류하고 있다. 그러므로 '건축계획'의 항목명을 541 '건축이론'으로 바꾸어 그 안에 포 함시키고 $\mathrm{KDC}$ 6판의 전개를 유지한 채, 540.9 에 건축사를 전개하는 방법을 제안한다.

또한 초가집이나 기와집을 포함한 한옥, 즉
한국 전통 건축물에 대한 분류는 별도의 목에 배치한 NDC의 사례처럼 541-549까지 이어지 는 건축학의 구조에서는 별도의 목으로 두기가 쉽지 않다. 그러나 549 '각종 건물' 아래의 549.1 '궁전, 성곽'에 '한국 전통 건축'을 부여하고, 한국 전통 건축물의 한 분야인 창경궁, 경복궁 등의 궁궐과 남한산성, 북한산성, 서울성곽 등 의 성곽은 549.1 아래에, 동서양의 궁전이나 성 곽은 그 용도에 따라 549.3 '공공건물', 549.7 '주거용건물', 549.8 '기타건물'에 분류할 수 있 다. 실제 $\mathrm{DDC}$ 의 경우 궁전에 해당하는 palace 는 728.8의 '크고 정교한 개인 주택(Large and elaborate private dwellings)'에 분류하고 있 다. 다만 $\mathrm{DDC} 728$ '주거용건물'은 저렴하고 작은 것부터 차츰 큰 건물을 배치하고 있으나 $\mathrm{KDC} 549$ '각종건물'은 궁궐과 성곽이 앞에 놓 이고 주거용주택이 뒤에 놓였다는 점을 감안 하여 '한국 전통 건축'은 궁궐, 성곽을 앞에 놓 고 그 뒤에 한옥을 놓아 그 아래 황토집, 초가 집, 기와집 등 한국 전통주택에 대한 문헌 분 류를 제안한다.

다섯째, $\mathrm{KDC} 6$ 판에서는 주택의 공간 배치와 설비를 549.7 '주거용 건물' 아래와 595.3의 '주 택관리 및 가정 설비'에서 같이 다루고 있다. 원 래 '주거용 건물' 아래의 공간 분류는 NDC 527 의 '주택건축'과 비슷한 전개를 따르고 있는데, $\mathrm{DDC}$ 에는 이런 구체적인 내용이 없다. 대신 $\mathrm{DDC}$ 에서는 640 '가정 및 가족 관리(Home \& family management)' 하위의 '주거 및 가정설 비(Housing and household equipment)', 즉 건축학이 아닌 주거학으로 분류하고 있다. 그러 므로 $\mathrm{KDC}$ 는 $\mathrm{DDC}$ 와 $\mathrm{NDC}$ 양쪽의 영향을 모두 받은 셈이다. 
〈표 6〉 KDC 6판의 수정 전개안

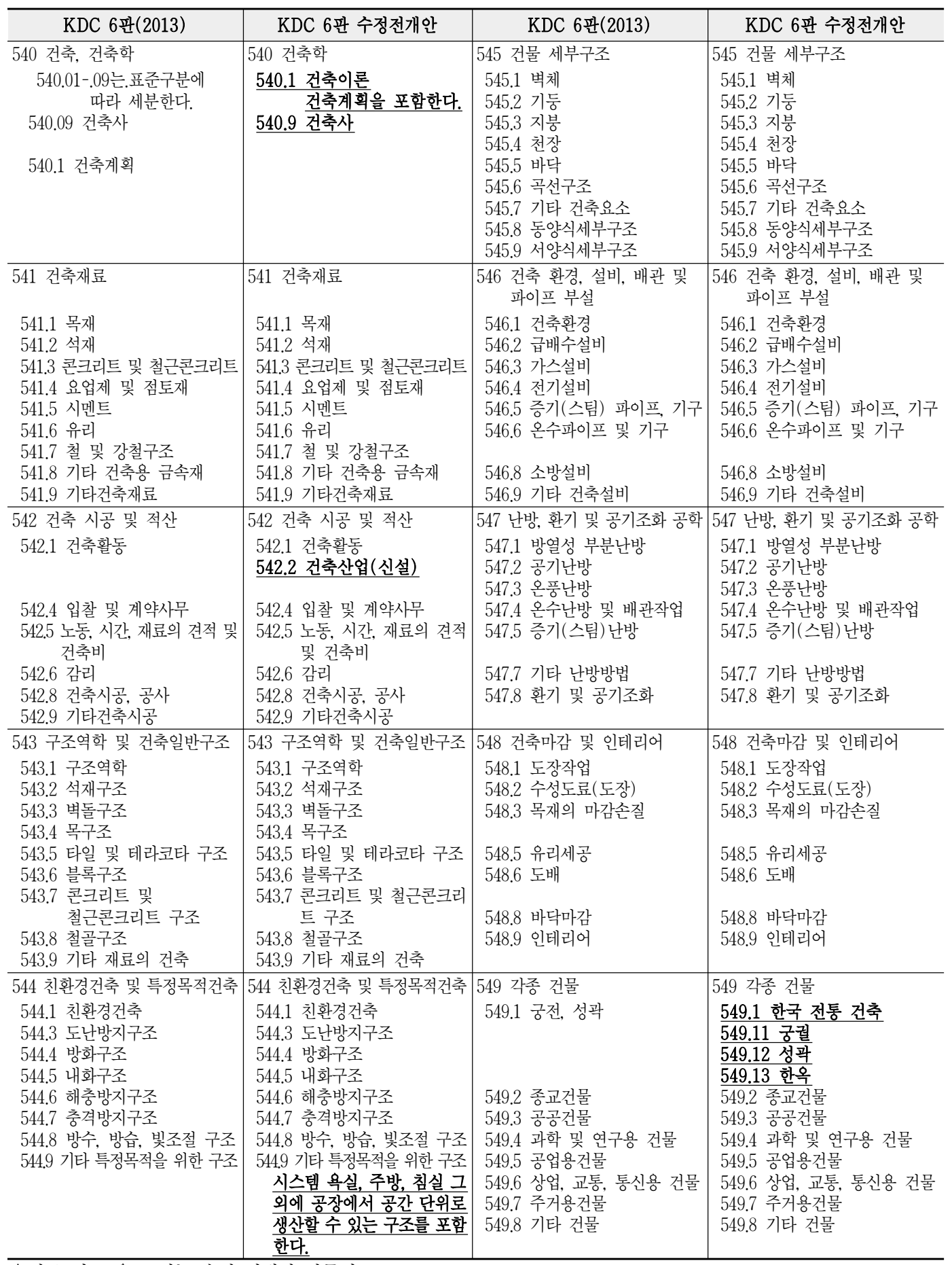

* 밑줄 친 굵은 글씨는 수정 전개한 항목임. 
여섯째, $\mathrm{KDC}$ 6판에서는 $\mathrm{NDC}$ 와 달리 '건축, 건축학' 항목에 건축업을 별도로 다루지 않는 다. 건축학은 학문의 특성상 실무를 맡고 있는 건축가나 건축사무소 등에서 발행한 도서도 전 체 발행문헌의 상당부분을 차지하며, '건축업'은 건축산업이나 건설사 등의 문헌에 대한 접근접 으로 유용할 것이다. 다만 $\mathrm{NDC}$ 에서 사용하는 용어를 그대로 사용하지 말고 한국 실정에 맞 게 건축산업으로 바꿀 필요가 있을 것이다. 이 는 건축회사 및 건축활동에서 발생하는 여러 사업과 관련한 문헌을 분류하는 항목이므로 '건축, 건축학'의 구조상 542 의 '건축 시공 및 적 산 아래에 들어가는 것이 타당하다. 542.2와 542.3 은 KDC 5판에서의 이동으로 항목이 비어 있으므로 542.1 의 '건축활동'에 이어지는 542.2 에 '건축산업'을 추가한다.

일곱째, $\mathrm{UDC}$ 표준3판에서는 $\mathrm{DDC}, \mathrm{KDC}$, $\mathrm{NDC}$ 에 없는 '간단한 장치와 도구(Simple units. Builders' hardware)에 대한 항목이 있다. 이는 건축과 관련한 도구나 장치 외에도 창문이나, 욕실, 문, 그 외에 공장에서 공간 단위로 생산할 수 있는 구조에 대한 분류도 가능한 항목이다. 창문이나 문 등의 세부 구조는 특별한 지시 없 이도 545 '건물 세부구조'에 분류할 수 있으나, 시스템 욕실이나 주방 등 최근 건축 산업분야에 서 공장에서 생산하여 조립하는 식의 주거 구조 나 건축 구조 등에 대해서는 관련 연구가 늘고 있으므로 항목의 추가가 필요하다. 그러므로 이 처럼 공장 등에서 생산되어 공간에 바로 넣을 수 있는 옥실이나 화장실 등의 구조는 조립식으 로 간편하게 만들 수 있는 특정 목적에 따른 구 조로 보고 544.9 '기타 특정목적을 위한 구조' 아래에 주기를 추가한다.

\section{5. 결론 및 제언}

$\mathrm{KDC} 6$ 판의 건축학은 5 판과 비교하였을 때 가장 많은 개정이 이루어진 분야이다. KDC 5 판에서는 건축공학과 건축술로 나뉘어 있던 건축학이 6 판에서 이용자들의 편의를 위해 건 축공학 쪽으로 합쳐졌지만 이는 건축의 예술적 인 요소를 다루기 어려울 수 있다. 무엇보다도 5 판을 사용하는 도서관에서는 새로운 분류표 를 따를 경우 610 건축술에 해당하는 기존 도 서들을 재분류해야 하는 문제가 발생한다. 5 판 의 내용이 6 판의 549 각종 건물의 세목으로 들 어가 있으므로, 549 각종 건물에 기 분류되었 던 도서들을 재분류하고 610 건축술에 해당하 는 도서를 이동해야하는 불편이 뒤따른다. 다 만 현재 610 은 공기호로 비어 있으므로 6 판 이 후의 개정판에서 새로운 학문분야로 전개시킬 수 있다.

『대한민국 국가서지 2012』를 기준으로 보면 610 '건축술'에는 4,996건, 611 부터 618 까지 각 종 건축물을 다루는 항목에는 전체 7,255건, 619 '장식 및 의장'은 3,545 건의 서지가 있어 전체를 재분류하는 작업이 쉽지 않다. 그러므로 $\mathrm{KDC}$ 를 사용하는 도서관은 6 판뿐만 아니라 이후 개 정판에 대하여 도입 여부를 신중히 결정하고 기 존 문헌의 재분류를 어떻게 할 것인지에 대한 원칙이 필요하다.

$\mathrm{KDC} 6$ 판에서는 공기호인 610 의 경우, 향후 타학문분야를 위해 재사용될 가능성이 있으나 $\mathrm{KDC}$ 를 사용하는 도서관들이 분류번호 이동에 적응할 기간을 가질 수 있도록 일정 기간 동안 비워둘 필요가 있다. $\mathrm{DDC}$ 의 경우 분류기호를 재배치하여 빈 번호의 경우 여러 판에 거쳐 비 
워 놓아 서로 다른 학문분야나 주제가 섞이지 않도록 배려하고 있으므로 이를 참조하는 것도 좋을 것이다.

또한 $\mathrm{KDC} 5$ 판의 610 예술분야 아래 전개 되 었던 510 '건축술'은 520 '건축, 건축학'으로 흡 수 통합되었기 때문에 대부분의 경우 분류기 호가 이전보다 길어질 수밖에 없다. 특히 '건축사'는 세목 이하에서 시대 구분과 지 역 전개가 가능하게 되며 분류번호가 이 전보다 훨씬 길어지게 되므로 주제 세분 의 가능성이라는 장점과 분류기호 증가로 인한 조기성 부족과 이용자의 불편이라는
단점을 동시에 가진다.

본 연구는 분류표의 십진분류표의 구조와 내 용적인 측면에 염두를 두었기 때문에 6 판의 활 용 과정에서 발생할 수 있는 문제나 불편, 수월 성에 관한 후속 연구가 필요하다. 건축학 분야의 분류표 사용 실태에 대한 조사도 윤춘섭(1995) 의 연구가 마지막이므로 실제 건축 분야의 전문 도서관을 대상으로 분류 적용 사례 연구가 필요 하다. 더불어 NDC 신정10판이 올해 안에 나올 예정이므로 NDC 최신판의 비교 분석 연구도 후 속연구로 이루어져 $\mathrm{KDC}$ 개정에 기초 자료가 지 속적으로 제공되어야할 것이다.

\section{참 고 문 헌}

곽철완 (2014). 도서관 분류법에 관한 국내 연구 동향. 한국비블리아학회지, 25(1), 173-191.

김수정 (2013). KDC 제6판 디자인학 분야 개선방안에 관한 연구. 한국비블리아학회지, 24(3), 53-72. 김연례 (2009). $\mathrm{KDC}$ 제5판 건축공학분야 분류체계 개선 방안. 한국도서관 - 정보학회지, 40(4), 401-425. 두산세계대백과사전 (2014. 5. 29). 건축학. Retrieved from http://www.doopedia.co.kr 여지숙, 공성훈, 오동근 (2013). KDC 제5판 건축학 분야 전개의 개선방안. 한국문헌정보학회지, 47(2), 359-376. http://dx.doi.org/10.4275/KSLIS.2013.47.2.359

윤춘섭 (1995). 한국 십진분류법(KDC) 중 건축관련 부분의 사용실태 및 실용성에 관한 연구. 大韓建 築學會論文集, 11(6), 49-56.

윤춘섭 (1999). 한국 십진분류법 $(\mathrm{KDC})$ 제4판 중 540 건축공학 부분의 개선방안에 관한 연구. 대한건축 학회논문집: 계획계, 15(12), 109-116.

윤춘섭 (2001). 한국 십진분류법(KDC) 제4판 중 610 건축술 부분의 개선방안에 관한 연구. 대한건축학 회논문집: 계획계, $17(2), 97-104$.

윤춘섭 (2002). 국내 인터넷 서점의 건축도서 분류에 관한 연구. 대한건축학회 논문집: 계획계, 18(2), 29-38.

이창수 (2008). UDC 표준판의 구조적 분석. 한국도서관정보학회지, 39(3), 299-320.

이희진, 김정현 (2013). 한국십진분류법 제6판 체육학 분야의 분류체계 개선방안. 한국비블리아학회지, 24(4), 301-317. 
정옥경, 이장익, 최정희 (2013). KDC 제6판 약학분야의 분류항목 전개방안. 한국비블리아학회지, 24(4), 281-299.

한국도서관협회 (2009). 한국십진분류법. 제5판. 서울: 한국도서관협회.

한국도서관협회 (2013). 한국십진분류법. 제6판. 서울: 한국도서관협회.

한국민족문화대백과사전 (2014. 5. 29). 건축학. Retrieved from http://encykorea.aks.ac.kr/

林清 (1995). 日本十進分流法. 新訂9版. 東京：日本圖書館協會.

British Standard Institution (2005). Universal Decimal Classification. London：British Standard Institution.

Dewey, M. (2011). Dewey Decimal Classification and Relative Index (23th ed.). Dublin, Ohio: OCLC.

Encyclopedia Britannica Online Korea (2014. 5. 29). 건축. Retrieved from http://preview.britannica.co.kr/

\section{- 국문 참고문헌에 대한 영문 표기}

(English translation of references written in Korean)

Chung, Ok-Kyung, Lee, Jangik, \& Choi, Jung-Hee (2013). The improvements of the pharmacy field in the 6th edition of the Korean Decimal Classification. Journal of the Korean Biblia Society for Library and Information Science, 24(4), 281-299.

Doopedia (cited 2014. 5. 29). Architecture. Retrieved from http://www.doopedia.co.kr.

Encyclopedia of Korean Culture (cited 2014. 5. 29). Architecture. Retrieved from http://encykorea.aks.ac.kr/

Kim, Soojung (2013). A study on the improvements of the design field in the 6th edition of the Korean Decimal Classification (KDC). Journal of the Korean Biblia Society for Library and Information Science, 24(3), 53-72.

Kim, Yeon-Rye (2009). The methods for the improvement of the KDC 5th edition of architecture engineering classifiction system. Journal of Korean Library and Information Science Society, 40(4), 401-425.

Korean Library Association (2009). Korea Decimal Classification. 5th edition. Seoul: Korean Library Association.

Korean Library Association (2013). Korea Decimal Classification. 6th edition. Seoul: Korean Library Association.

Kwak, Chul-Wan (2014). Trends in the current library classification research in Korea: A review 
of the literature in the past 10 Years. Journal of the Korean Biblia Society for Library and Information Science, 25(1), 173-191.

Lee, Chang-Soo (2008). An analysis of the structural characteristics of the UDC standard edition. Journal of Korean Library and Information Science Society, 39(3), 299-320.

Lee, Hee-Jin, \& Kim, Jeong-Hyen (2013). The improvements of the physical education field in the 6th edition of KDC. Journal of the Korean Biblia Society for Library and Information Science, 24(4), 301-317.

Yeo, Ki-Suk, Kong, Song-Hoon, \& Oh, Dong-Geun (2013). Improvements and modifications of the subject, architecture engineering, in the 5th edition of the Korean Decimal Classification. Journal of the Korean Society for Library and Information Science, 47(2), 359-376. http://dx.doi.org/10.4275/KSLIS.2013.47.2.359

Yoon, Choon-Sup (1995). A study on the popularity and particality of KDC(Korean Decimal Classification) with particular reference to architecture. Journal of Architecture Institution of Korea, 11(6), 49-56.

Yoon, Choon-Sup (1999). The study on the Korean Dicimal Classification with particylar reference to architecrure engineering section. Journal of Architecture Institution of Korea Planning \& Design, 15(12), 109-116.

Yoon, Choon-Sup (2001). A study on the Korean Decimal Classification with particular reference to architecture section. Journal of Architecture Institution of Korea Planning \& Design, 17(2), 97-104.

Yoon, Choon-Sup (2002). A study on the architectural classification of online bookshops. Journal of Architecture Institution of Korea Planning \& Design, 18(2), 29-38. 